Pacific Journal of Mathematics

ON NORMALOID OPERATORS 


\section{ON NORMALOID OPERATORS}

\section{H. SHETH}

The purpose of the present paper is to extend an earlier theorem of the author's on hyponormal operators to the following, on normaloid operators.

THEOREM. Let $N$ be an operator such that $N-z I$ is normaloid for all complex values of $z$. If $A N=N^{*} A$, for an arbitrary operator $A$, for which $0 \notin \mathrm{Cl}(W(A))$, then $N=N^{*}$.

2. Notations. We consider bounded linear operators defined on a Hilbert space $H$. As usual, the symbols $s(T), \Sigma(T), W(T)$ and $\mathrm{Cl}(W(T))$ stand for the spectrum of an operator $T$, the closed convex hull of $s(T)$, the numerical range of $T$ and the closure of $W(T)$ respectively.

An operator $T$ is said to be normaloid if $\|T\|=\sup \{|z| ; z \in s(T)\}$ and hyponormal, if $T^{*} T-T T^{*} \geqq 0$. It is known that if $T$ is hyponormal, then $T$ is normaloid and $T-z I$ is also hyponormal for all complex numbers $z$.

When the original version of this paper was submitted, the referee told me of [3] then existing as a preprint and this makes possible the following shorter proof.

Proof of Theorem. Since $A N=N^{*} A$ and $0 \notin \mathrm{Cl}(W(A)), s(N)$ is real [3]. Also $\Sigma(N)=\mathrm{Cl}(W(N))$ for such a normaloid operator $N$ [1]. Hence $\mathrm{Cl}(W(N))$ is real. This completes the proof of theorem.

The corresponding result for hyponormal operators now follows as corollary from this theorem and the remark made above.

The author expresses his thanks to Prof. U. N. Singh and the referee for their comments and suggestions.

\section{REFERENCES}

1. T. Saito and T. Yoshino, On a conjecture of Berberian, Tohoku Math. J. 17 (1965), 147-149.

2. I. H. Sheth, On hyponormal operators, Proc. Amer. Math. Soc. 17 (1966), 998-1000. 3. James P. Williams, Operators similar to their adjoints, (to appear in Proc. Amer. Math. Soc.)

Received April 15, 1968.

M. S. UNIVERSity OF BARODA,

BARODA INDIA 



\section{PACIFIC JOURNAL OF MATHEMATICS}

\section{EDITORS}

\author{
H. ROYDEN \\ Stanford University \\ Stanford, California \\ R. R Phelps \\ University of Washington \\ Seattle, Washington 98105
}

\author{
J. Dugundui \\ Department of Mathematics \\ University of Southern California \\ Los Angeles, California 90007
}

RICHARD ARENS

University of California

Los Angeles, California 90024

\section{ASSOCIATE EDITORS}
E. F. BeCKENBACH
B. H. NeUmanN
F. WolF
K. YosidA

\section{SUPPORTING INSTITUTIONS}

\author{
UNIVERSITY OF BRITISH COLUMBIA \\ CALIFORNIA INSTITUTE OF TECHNOLOGY \\ UNIVERSITY OF CALIFORNIA \\ MONTANA STATE UNIVERSITY \\ UNIVERSITY OF NEVADA \\ NEW MEXICO STATE UNIVERSITY \\ OREGON STATE UNIVERSITY \\ UNIVERSITY OF OREGON \\ OSAKA UNIVERSITY \\ UNIVERSITY OF SOUTHERN CALIFORNIA
}

\author{
STANFORD UNIVERSITY \\ UNIVERSITY OF TOKYO \\ UNIVERSITY OF UTAH \\ WASHINGTON STATE UNIVERSITY \\ UNIVERSITY OF WASHINGTON

$* * * * *$
AMERICAN MATHEMATICAL SOCIETY
CHEVRON RESEARCH CORPORATION
TRW SYSTEMS
NAVAL WEAPONS CENTER

The Supporting Institutions listed above contribute to the cost of publication of this Journal, but they are not owners or publishers and have no responsibility for its content or policies.

Mathematical papers intended for publication in the Pacific Journal of Mathematics should be in typed form or offset-reproduced, double spaced with large margins. Underline Greek letters in red, German in green, and script in blue. The first paragraph or two must be capable of being used separately as a synopsis of the entire paper. It should not contain references to the bibliography. Manuscripts, in duplicate if possible, may be sent to any one of the four editors. Please classify according to the scheme of Math. Rev. 36, 1539-1546. All other communications to the editors should be addressed to the managing editor, Richard Arens, University of California, Los Angeles, California, 90024.

50 reprints are provided free for each article; additional copies may be obtained at cost in multiples of 50 .

The Pacific Journal of Mathematics is published monthly. Effective with Volume 16 the price per volume (3 numbers) is $\$ 8.00$; single issues, $\$ 3.00$. Special price for current issues to individual faculty members of supporting institutions and to individual members of the American Mathematical Society: $\$ 4.00$ per volume; single issues $\$ 1.50$. Back numbers are available.

Subscriptions, orders for back numbers, and changes of address should be sent to Pacific Journal of Mathematics, 103 Highland Boulevard, Berkeley, California, 94708.

PUBLISHED BY PACIFIC JOURNAL OF MATHEMATICS, A NON-PROFIT CORPORATION

Printed at Kokusai Bunken Insatsusha (International Academic Printing Co., Ltd.), 7-17. Fujimi 2-chome, Chiyoda-ku, Tokyo, Japan. 


\section{Pacific Journal of Mathematics}

Vol. 28, No. 3

May, 1969

Jon F. Carlson, Automorphisms of groups of similitudes over $F_{3} \ldots \ldots \ldots$

W. Wistar (William) Comfort, Neil Hindman and Stelios A. Negrepontis,

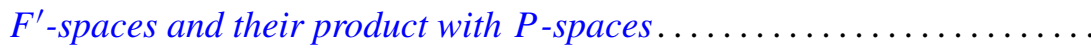

Archie Gail Gibson, Triples of operator-valued functions related to the unit

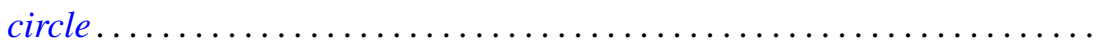

David Saul Gillman, Free curves in $E^{3}$

E. A. Heard and James Howard Wells, An interpolation problem for

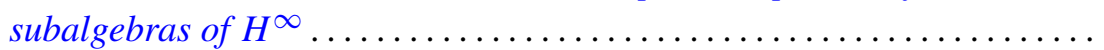

Albert Emerson Hurd, A uniqueness theorem for weak solutions of symmetric

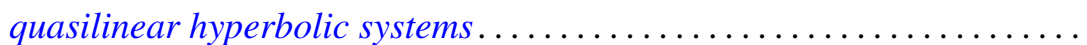

E. W. Johnson and J. P. Lediaev, Representable distributive Noether

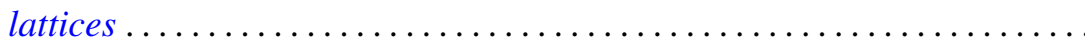

David G. Kendall, Incidence matrices, interval graphs and seriation in

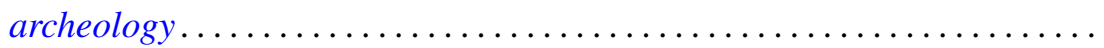
565

Robert Leroy Kruse, On the join of subnormal elements in a lattice ....... 571

D. B. Lahiri, Some restricted partition functions; Congruences modulo 3 .... 575

Norman D. Lane and Kamla Devi Singh, Strong cyclic, parabolic and conical differentiability........................................

William Franklin Lucas, Games with unique solutions that are

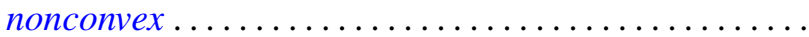

Eugene A. Maier, Representation of real numbers by generalized geometric series.

Daniel Paul Maki, A note on recursively defined orthogonal polynomials ...

Mark Mandelker, $F^{\prime}$-spaces and z-embedded subspaces ...

James R. McLaughlin and Justin Jesse Price, Comparison of Haar series with gaps with trigonometric series

Ernest A. Michael and A. H. Stone, Quotients of the space of irrationals ....

William H. Mills and Neal Zierler, On a conjecture of Golomb ...

J. N. Pandey, An extension of Haimo's form of Hankel convolutions ...

Terence John Reed, On the boundary correspondence of quasiconformal mappings of domains bounded by quasicircles...

Haskell Paul Rosenthal, A characterization of the linear sets satisfying Herz's criterion.

George Thomas Sallee, The maximal set of constant width in a lattice...

I. H. Sheth, On normaloid operators

James D. Stasheff, Torsion in BBSO ...

Billy Joe Thorne, A - P congruences on Baer semigroups.

Robert Breckenridge Warfield, Jr., Purity and algebraic compactness for

modules... 